\title{
Relationship between Environmental Damage and Corruption Cases in Indonesia
}

\author{
Muslihudin Muslihudin ${ }^{1 *}$, Eko Hendarto ${ }^{2}$, Rin Rostikawati ${ }^{1}$, Rili Windiasih ${ }^{1}$ Tyas Retno Wulan ${ }^{1}$. \\ 1. Faculty of Social and Political Sciences, Jenderal Soedirman University, Purwokerto, Indonesia. \\ 2. Faculty of Animal Science, Jenderal Soedirman University, Purwokerto, Indonesia.
}

\begin{abstract}
Environment and corruption are two very popular concepts in the last few decades. Both reflect on the negative side in society. Environmental issues are becoming popular because of many environmental problems that arise not only locally, regionally or nationally but also in the international level. Likewise, corruption is widely discussed and demonstrated especially in Indonesia since the reform era, 1998. The relationship between environment and corruption is more of a causal relationship, where the environment plays a role, while corruption is the cause. The form of corruption that causes environmental damage is; 1) granting permission from regional heads to entrepreneurs who are bribed, so that provisions in the licensing process are not considered properly; 2) corruption in the Amdal process, in which employers give bribes to the parties involved in the Amdal process; 3) corruption of illegal levies against entrepreneurs so that entrepreneurs make compensation calculations by way of externality of production costs to the environment, as a consequence of high costs borne by the entrepreneurs. Some examples of corruption cases show the corruption of a certain kind has made the environment a victim. The environmental aspect should be considered in the judicial process of corruption cases that have an impact on the environment, so the public's concern for the environment is getting stronger.
\end{abstract}

Keywords: environment; corruption; regional head; entrepreneur; externality.

\section{Introduction}

Environmental issues have long been a concern of the community both at the regional, national and international level. The world's consonant towards the environment is markedly begun since the year of the high-level conference on the environment in Stockholm 5 June 1972. The people of Indonesia have grown their concern for the environment since 1982, marking the number 4 law on the first principles of environmental management. [1] It explains that the growing public awareness of the environment is actually a reflection of the empirical reality in which their environmental conditions have already occurred some damage. The environmental damage since that time has not diminished but continues even more intensive damage.

Environmental damage problems both abiotic, biotic and culture components occur as a result of human activities such as high carbon levels as an effect of various daily activities of the community, damage and pollution due to mining activities [2]. The massive environmental damage in various places in almost all parts of the country shows that the ability of the Indonesian people to carry out environmental management or common property is very weak. This

* Corresponding author: muslihudin1963@yahoo.com also shows that from the national level to the communal level there has been a breakdown in cultural values. The very high cultural value of the level of damage is the value of fairness and honesty value which should be free from corruption [3].

Corruption as an issue is more recent than environmental issues in Indonesia. The issue of corruption began to bloom since the start of the reform era in1980s. The change of the new order regime to the reform order was also driven by the issue of corruption, collusion and nepotism. Since then the issue of corruption until now is still always warm and adorn the media both electronic and print. Since then, studies and references to corruption have grown. Even in the world of academics also increasingly discuss the issue of corruption.

The issue of corruption is so widespread in the country. It is indeed a reflection of empirical reality, in which cases of corruption is a lot happening. [4] informed that the Indonesia Corruption Perception Index (IPK) in 2016 scored 37 in the range 0-100 (0 means very corrupt and 100 means very clean). Indonesia ranked 90th out of 176 countries surveyed. The ASEAN Region of Indonesia occupies the fourth position after Singapore, Brunei and Malaysia, while below are the 
Philippines, Thailand, Vietnam, Laos, Myanmar and Cambodia.

Since the reformation era until now Indonesia has their president changed 5 (five) times, yet it has not been able to eradicate corruption. Corruption does not stop but in certain cases it still runs and even grows. Thus many parties feel ironic, they said the reformation era was determined to eradicate corruption but the practice of corruption still happens here and there. Such conditions, it seems corruption has become a systemic disease. When corruption has reached the systemic stage, which means becoming a habit and being part of everyday life that seems justified by the values that exist, makes us realize that this disease has indeed become a chronic society disease. A separate concern that would be less difficult to eradicate than to eradicate the outbreak of dengue fever, bird flu, and other endemic diseases.

Environmental-related studies and corruption also begin to exist even though they appear to be less than environmental studies or individual corruption. Therefore, this study aims to reveal about the relationship between the environment with corruption. $[5,6,7]$ concludes that corruption is not only related to social and economic growth but also relates to environmental sustainability. Likewise, [8] states that there is a significant relationship between corruption and environmental sustainability.

\section{Material and Method}

The research method in this study is a qualitative research method that focuses on proven corruption cases in Indonesia. The subject matter or objectives of the review are news stories of corruption cases published in print, as well as online and scientific articles. The method of analysis is the content analysis which according to [9] that this method essentially analyses not what is communicated, but how they communicate it. Content analysis is generally used to investigate how the media transfer values, opinions and attitudes that exist in society.

[10] It explains that content analysis is a technique of collecting and analysing the contents of a text. Content, in this case, is a word, meaning, image, symbol, idea or some message that can be communicated. Furthermore [11] explains that content analysis includes reading, counting, categorizing various indicators relating to the issues raised in this study. Then It is displayed in the form of descriptions, narration, graphics, tables and pictures to describe the conditions or variants that exist in the findings.

\section{Result and Discussion}

The phenomenon of corruption in Indonesian soil is actually a long-standing symptom. However, this phenomenon has only been voiced since the end of the New Order era in power. Along with the declining positive sentiment of the regime, the issue of corruption is increasingly widely voiced, especially beginning from academics who dare to criticize the weaknesses of the government at that time. After entering the reform era, the mass media of both print and electronic spontaneously participated in publicly reporting corruption issues openly. This is in line with the democratization and press freedom that is conducive to corruption issues. Cases of corruption are published in the media almost every day. Various types of variants, fields, forms, actors, institutions of corruptors are also reported. [12] as a spokesman for anti-corruption agencies reported that within 6 months from 1 January to 30 June 2017, there were 226 cases of corruption. The case with the number of the 587 suspects had cost the state Rp 1.83 trillion and the bribe Rp 118.1 billion.

Some of the findings of corruption cases linked to the destruction of the environment in this study are as follows.

\subsection{Illegal Logging}

[13] It is reported that many accused illegal loggers were acquitted. As of May 2007, out of 116 cases of Forest Operation II in Papua, 29 cases have been convicted. Of that total, 17 of them were acquitted purely free. The rest were lightly sentenced: 2-2.5 months in prison. The Indonesian Centre for Environmental Law data speaks the same: Of the 155 cases of illegal logging investigated by the Police in 2005 , only 10 cases could be brought to justice.

The case of corruption in the forestry sector is no longer a new case. Recorded since the Commission stood in 2003 until August 2012 alone there are seven cases of forest sector corruption that has been handled. Former Minister of Forestry M.S Kaban once said that the state losses due to illegal logging practices in the forestry sector reached $\mathrm{Rp} 30$ trillion or around $\mathrm{Rp} 2.5$ trillion per month.

The practice of corruption is also considered to have a significant share in causing ecological damage whose material losses cannot be measured with certainty. From the examination of environmental and forestry ministry data, the KPK found that some of the recorded production data was much lower than the volume of timber harvested from natural forest in Indonesia.

\subsection{Riau Governor Annas Maamun}

In September 2014, the Corruption Eradication Commission (KPK) arrested Riau Governor Annas Maamun after the 72-year-old received a bribe from a palm oil businessman. The smoke haze from peat fires continues to blanket some parts of Indonesia to neighbour countries. However, the crucial cause of fire that escaped attention is corruption [14].

The Public Prosecutor concludes that Annas is proven to be legitimate and convincing according to the guilty law of committing criminal acts of corruption as stipulated and punishable by criminal sanction in Article 12 letter b, Article 11 and Article 12 Sub-Article a Corruption Act. The threat of maximum penalty of 20 years in prison and a maximum fine of $\mathrm{Rp} 1$ billion. 
The court handed down the defendant to the defendant Annas Maamun in the form of imprisonment for six years minus while in detention with the order that the defendant should remain in custody and added a fine of Rp250 million subsidies for five months of confinement, "said Irene reading out the demands. The prosecutor said the defendant did not support the government's program in eradicating corruption and as head of the region was not a role model for the community.

\subsection{Non-active Governor Nur Alam}

Southeast Sulawesi's non-active governor Nur Alam as a suspect in corruption case of abuse of authority in the approval and issuance of mining business permit (IUP) in Southeast Sulawesi region in 2008-2014. The Corruption Eradication Commission (KPK) for the first time uses environmental damage to assess the state's financial losses. This was applied in the prosecution of the defendant Southeast Sulawesi's inactive governor Nur Alam.

In the case of Nur Alam, the prosecutor considered that the National Mandate Party's politician's actions have resulted in the loss of or environmental function at the mine site of Kabena Island managed by PT Anugrah Harisma Barakah. State losses amounted to $\mathrm{Rp} 2.7$ trillion due to nickel mining activities conducted by PT Anugrah Harisma Barakah (AHB) on Kabaena Island. From the results of the research, there are three types of calculation of losses due to environmental damage; first, total losses due to ecological damage; second, environmental economic losses and the third calculate the cost of environmental recovery.

The calculation uses the reference of Ministerial Regulation No. 7 of 2014 on Environmental Losses Due to Pollution and Environmental Damage. In addition, in direct observation found damage to land and mining activities beyond the permits granted to PT AHB. According to prosecutors, Nur Alam commits unlawful acts in granting the Approval of Mining Area Arrangement, Approval of Mining Business License (IUP) Exploration. Permission and approval are issued without following the procedure. As a result, PT AHB obtained a profit of Rp 1.5 trillion. Once calculated with the profits earned by the corporation, the state losses caused reached $\mathrm{Rp} 4.3$ trillion.

\subsection{Environmental Impact Assessment (EIA) Corruption}

Corruption that occurred during the process of preparing the Environmental Impact Assessment (EIA) contributed to the worsening of the situation. Development becomes uncontrollable and triggers other environmental and social problems. EIA compilers are almost always approved by their bribes. According to the Corruption Eradication Commission (CEC) study in 2013 and 2015 related to bribery or the role of licensing and the loss of state revenue potential shows this. The causes of poor EIA products are also caused by the EIA
Assessment Commission (EAC) which is more often in favor of investors or companies rather than the community and the environment. Corruption cases related to the AMDAL process and have been disclosed include the following.

EIA corruption is the Source of Environmental Damage. This worsens the situation, the development becomes uncontrollable, triggering environmental and social problems. "The EIA compilers (environmental impact analysis) have almost always endorsed their studies through bribery. According to the CEC (Corruption Eradication Commission) review in 2013 and 2015 relating to bribery or licensing roles and loss of potential state revenues shows that. The cause of poor EIA product is also caused by EIA Appraisal Commission which more often sides with the investor than the society and environment. EIA corruption cases that have been revealed are as follows.

\subsubsection{Environmental Impact Assessment in Cilegon}

KPK has previously arrested the Mayor of Cilegon TIA (Tubagus Iman Ariyad), Head of Licensing Agency of Integrated and Investment Cilegon Ahmad Dita Prawira, and three top officials from PT Krakatau Industrial Estate Cilegon. They are allegedly involved in bribery in order to smoothen the recommendation of EIA of Transmart shopping center development. TIA granted an EIA license, which initially requested Rp 2.5 billion for the construction of Transmart. Then the bargain was finally agreed upon by Rp 1.5 billion, "The company then confused to spend Rp 1.5 billion without a clear designation. Br Brantas Abipraya and PT Krakatau Industrial Estate Cilegon then outsmarted by transferring it to Cilegon United Football Club for Rp700 million and Rp 800 million by bank transfer on Wednesday 19 September 2017 as a form of Corporate Social Responsibility (CSR).

\subsubsection{Environmental Impact Assessment in Kutai Kertanegara}

Kutai Kertanegara Regent, Rita Widyasari, has been a suspect in the corruption case KPK receiving gratuities of Rp 436 billion. One mode of corruption is that every entrepreneur is asked to pay $\mathrm{Rp} 60$ million every EIA permition in Kutai Kartanegara. Every entrepreneur requesting environmental permit and environmental impact analysis permit (EIA) at the Regional Environment Agency of Kutai Kartanegara Regency is required to pay $\mathrm{Rp} 60$ million. The fee is granted for permission to be issued. It was said by the Commissioner of PT Agronusa Sartika Hamsin when testifying at the Corruption Court Jakarta, Wednesday (7/3/2018). Hamsin testified to the defendant Kutai Kartanegara.

\subsubsection{Bribery in EIA of Reclamation in Jakarta}

After the reclamation permit has been issued by the Governor of Jakarta since 2010, the foundation of 
developer activity to make the building on the readymade island is the Zone Regulation of the Coastal Zone and Small Islands and the Strategic Plan of the North Coast. The two rules were cancelled by the Regional House of Representatives because the Corruption Eradication Commission arrested Mohamad Sanusi, Gerindra politician, after receiving bribes from President Director of Agung Podomoro Land Ariesman Widjaja on March 31, 2016.

Podomoro has finished making the foundation of Pulau G. Urukannya reached 18 percent when stopped. The property company also has long advertised and sold apartments and offices on the 161-hectare island. Ariesman joined the suspect for allegedly ordered his subordinates to give Rp 1.1 billion to Sanusi, Chairman of the DPRD Development Commission of Jakarta. He is not a member of the Legislation Body which decided the two Draft rules, but allegedly plays a role in governing members of the Board to design developer tactics to tackle the rules against them.

\subsection{Coal Corruption Cases}

There are many corrupt practices along the value chain of coal. Many corruption cases have been revealed about licensing and negligence in enforcing the rules on mining and post mining operations. Jakarta, March 23, 2017. Together with communities affected by the coal industry, civil society coalitions from Greenpeace, Walhi, Jatam, 350 Indonesians, and the Auriga Nusantara Foundation undertook mass action to urge the government to escape dependence on fossil fuels, especially coal. Today's peaceful action is part of the Break Free global movement that calls for an end to the coal era for a healthy and safe future.

Thousands of times participating in this peaceful action came from various regions, including Batang, Labuan, Pelabuhan Ratu, Cilacap, Jepara, Indramayu, Cirebon, Bengkulu and representatives from East Kalimantan. Peaceful action is aimed at providing support to the Corruption Eradication Commission (KPK), to thoroughly investigate corruption practices in the coal industry, both in the mining sector and in the generation of electricity, particularly in those affected areas.

Some examples of corruption cases shown above show that corruption with certain types has made the environment a victim. Therefore, the environmental aspect should be considered in the judicial process of corruption cases that have an impact on the environment. So far, although corruption has been considered an extraordinary crime (still extraordinary crime) is still based on the consideration that corruption caused massive damage and widely affect the lives of the people of Indonesia. In many pieces of literature it is mentioned that corruption leads to a decline in national competitiveness, disrupting economic growth, generating enormous social costs, and ultimately increasing poverty levels. No explicit mention of environmental damage has not been expressly stated. It is time for the mission [15] to always be the basis for handling corruption cases either directly related to environmental destruction or not directly damaging the environment.

\section{Conclusions}

Corruption associated with environmental destruction there are several cases, among others; 1) Provision of licensing from the regional head (Governor and Regent) to the entrepreneur by not paying attention to the proper regulations. Thus the corruptors get rewarded bribes from the entrepreneurs in order to smooth the business licensing. 2) Corruption in the Environmental Impact Analysis (EIA) process, in which case it is a bribe from businessmen seeking to get recommendations for their action plans. The pattern of corruption in the case of collusion between the project owner with the compilers of the EIA and the EIA assessment commission, so that they are more favorable to the entrepreneurs than to the interests of society and the environment. 3) Corruption by the Regional Head that collects a sum of money against all entrepreneurs who apply for EIA. With such a pattern, the cost of production becomes high for every entrepreneur who in turn entrepreneurs do the externality of their production costs to the environment.

This pattern makes the environment a victim of a series of production processes that are interfered with corruption. With the example of the corruption case seen above, it shows that corruption with certain types has made the environment a victim. Thus, the environmental aspect should be one of the considerations in the judicial process of corruption cases that indeed have an impact on the environment so that public awareness of the environment and corruption is getting stronger. Corruption that has an effect on environmental damage must be added to the punishment. Thus, carbon reduction programs, environmentally sound development, waste reduction programs and so on, will be helped from the social aspects related to corruption.

\section{References}

1. J.A. Hannigan, Environmental Sociology, A Social Constructionist Perspective, Routledge, New York (1995).

2. M. Muslihudin, A.N. Bambang, E. Hendarto, T.T. Putranto, The Impact of Traditional Gold Mining in Gumelar, Banyumas, Indonesia. Ecology. Environment \& Conservation. 24 (2) : 2018; pp. 607-613 (2018).

3. T. Pranadji, Greed, Poverty and Environmental Damage, National Seminar V of the Indonesian Sociology Association (ISI) with the theme "Indonesia that is Corruption Free, Rukun dan Mandiri", 20 September 2005, BKKBN Meeting Building, Jakarta (2005).

4. Transparency International, Indeks Persepsi Korupsi Indonesia 2016, Jakarta (2017). 
5. R. Lopez, S. Mitra, Corruption, pollution and the Kuznets environment curve. Journal of Environmental Economics and Management 40(2):137-150 (2000).

6. R. Damania, P.G. Fredriksson, J.A. List, Trade liberalization, corruption, and environmental policy formulation: theory and evidence. Journal of Environmental Economics and Management 46(3):490-512 (2003).

7. H. Welsch, Corruption, growth, and the environment: a cross-country analysis. Environment and Development Economics 9:663693 (2004).

8. S. Morse, Is corruption bad for environmental sustainability? a cross-national analysis. Ecology and Society 11(1): 22. [online] URL: http://www. Ecology and society. org/vol11/iss1/art22 (2006).

9. A.G. Johnson, Human Arrangement, an introduction to Sociology, Harcourt Brace Jovanovich, Publisher, New York (1996).
10. L.W. Neuman, Social Research Methods: Qualilative and Quantitative Approaches. Boston: Allyn and Bacon (2013).

11. M. Muslihudin, J. Santoso, R. Rostikawati, Korupsi dalam Pandangan Pejabat, Pengamat dan Rakyat di Wilayah Kabupaten Banyumas, Fisip Unsoed, Purwokerto (2007)

12. W. Alamsah, in 6 Months 226 Corruption Cases Affected the Country of Rp 1.83 Trillion, Indonesia Corruption Watch. Jakarta (2017).

13. Tempo, Illegal logging and money laundering, accessed from https: // national. tempo. co / read / 112877 / illegal-logging-and-money laundering (2007).

14. R. Henschke, There is corruption behind Indonesia's haze, accessed at http: // www. bbc.com/indonesia/ berita_indonesia / 2015/10 / 151017. (2015).

15. Law Number 32 of 2009 Concerning Environmental Protection and Management, Republic of Indonesia (2009). 